\title{
Assured Income of Beneficiary and Non-Beneficiary through Different Activities Implemented under IWDP Programme in Nagaland
}

\author{
S. Kanitoli Chishi and Amod Sharma*
}

Department of Agricultural Economics, Nagaland University SASRD, Medziphema Campus, District: Dimapur - 797 106, Nagaland, India

*Corresponding author

\section{A B S T R A C T}

\section{Keywords}

IWDP,

Beneficiaries, Nonbeneficiaries, Assured, Income, Activities

Article Info

Accepted:

17 May 2019

Available Online:

10 June 2019
The present study to access the assured income through different activities implimented under IWDP with especial reference to the beneficiaries and non-beneficiaries for the purpose two districts from the Nagaland state viz; Dimapur and Zunheboto were selected purposely due to the maximum number of area covered under watershed in the zone further two blocks from each district were randomly selected which was finally having 8 numbers of watersheds areas were selected. In the second stage of sampling a multi stage random sampling was used for the selection of beneficiary and non-beneficiary viz; 160 respondents ( 80 beneficiaries and 80 non-beneficiaries) were selected randomly from identified watershed areas. Study reveals that the average monthly income of the beneficiary and non-beneficiary. It was found that there is an increase in the income of for both beneficiary and non-beneficiary but comparatively beneficiary has more increased income. The medium farmers have higher increased income of Rs 541.00/- as compared to large farmers with Rs 493.00/-, semi-medium with Rs 440.00/- and small with Rs 280.00/-, respectively in the rural areas of Nagaland.

\section{Introduction}

Watershed Development Programmes (WDPs) have been accorded high priority in India's development plan (Anon, 2016).

These programmes have been initiated in India to improve and sustain productivity and the production potential of the dry and semiarid regions of the country through the adoption of appropriate production and conservation techniques. The WDP approach seeks to improve and develop all types of land viz., government forest, community land and private land; that fall within a particular watershed. It is a holistic approach to improve and develop the economic and natural resource base of dry and semi-arid regions (Anon. 2017). Watershed is defined as a hydro-geological unit area from which the rainwater drains through a single outlet. Watershed development refers to the conservation, regeneration and judicious use of all the natural resources (like land, water, plants, animals) by human beings (Walling and Sharma, 2015). 
A watershed provides a natural geohydrological unit for planning any developmental initiative (Sharma, 2012; Tangjang and Sharma, 2018). The approach would be treatment from "ridge to valley". The present study having the two specific objectives viz., To evaluate the resource useefficiency of the sample farmers, and to study the marginal value product of Integrated Watershed Management Programme.

The programme have stressed upon improvement of wasteland, runoff reduction, water conservation and protective irrigation mechanism in all areas including desert prone areas and drought prone areas. Development programs, envisaged under its purview include almost every activity which concerns land, water and bio-mass production. Experiences have shown that watershed as a base is very effective in use and management of land and water resources. With increasing awareness about the problems related to environment, use of watershed terminology is becoming popular and moreover in view of their potential for growth, improvement in income levels and augmenting the natural resource base of the disadvantaged regions of the country (Sharma and Sharma, 2008).

\section{Materials and Methods}

The present study is related to IWMP scheme, which is working as per the guideline of Central government with the help of Ministry of Agriculture, Government of India. Development projects require long period of time to reap benefits. Therefore for economic appraisal of development projects, it is essential that the project has been in operation for quite some time. Since the intensive IWMP started in 2008-09, so it is worth, while to study its impact. Since the data of the initial period cannot be compared with the data of recent years. It is more scientific and practical to compare the economy of the beneficiaries and non-beneficiaries covered in the area of IWMP schemes.

The IWMP was launched in 2008-09 in all 11 district viz., Dimapur, Kohima, Kiphire, Longleng, Mokokchung, Mon, Phek, Peren, Tuensang, Wokha and Zunheboto of Nagaland, out of these districts two districts namely, Zunheboto and Dimapur districts of Nagaland selected because of the fact that it is expected to provide all the relevant information and hence can conveniently be obtained for conducting this study (Anon., 2017).

The project area also has a good network of infrastructure and allied activities related to the scheme such as development agencies, nationalized banks, well-established marketing and communication facilities etc. Keeping all the above facts, both districts of Nagaland are therefore purposively selected, while two blocks were selected from the selected districts, while from each blocks 2 villages (8 villages in total) were selected randomly and then 10 beneficiaries and 10 non-beneficiaries ( 20 cases in total from each villages), so 80 numbers each of beneficiaries and non-beneficiaries were selected by following the simple systematic randomly sampling techniques with the two (2) specific objectives to conduct the present study:

To examine the different activities adopted under Integrated Watershed Management Programme (IWMP), and

To study the average assured monthly income by the beneficiaries and non-beneficiaries implementation of Integrated Watershed Management Programme (IWMP).

\section{Results and Discussion}

Table 1 reveals that the different Entry point activity carried out under IWMP in Nagaland. 
Table.1 Different Entry point activity carried out under IWMP in Nagaland

\begin{tabular}{|c|c|c|c|}
\hline S.N. & Name of the works & $\begin{array}{l}\text { No of } \\
\text { village }\end{array}$ & $\begin{array}{l}\text { Area(Ha)/No/Running } \\
\text { feet }\end{array}$ \\
\hline 1. & Marketing Shed & 115 & 125 Nos. \\
\hline 2. & Ring-well & 19 & 25 Nos. \\
\hline 3. & Water tank / pond / reservoir & 393 & 488 Nos. \\
\hline 4. & Community hall/repair or renovation of community hall & 56 & 61 Nos. \\
\hline 5. & Toilets & 75 & 946 Nos. \\
\hline 6. & Footstep & 66 & 6121 feet \\
\hline 7. & Fencing of project site & 16 & 206 rolls \\
\hline 8. & Generator & 4 & 4 Nos. \\
\hline 9. & $\begin{array}{l}\text { Community kitchen / guest house/building/post harvest } \\
\text { storage unit }\end{array}$ & 32 & 36 Nos. \\
\hline 10. & Renovation of school building & 6 & 6 Nos. \\
\hline 11. & Rostrum & 18 & 18 Nos. \\
\hline 12. & Approach road / repairing of road & 18 & $25.78 \mathrm{Km}$ \\
\hline 13. & Community fishery pond & 3 & 3 Nos. \\
\hline 14. & Bamboo charcoal making hearth & 1 & 1 Nos. \\
\hline 15. & Waiting shed & 66 & 67 Nos. \\
\hline 16. & Culvert & 8 & 8 Nos. \\
\hline 17. & Street light / Solar light & 3 & 3 Nos. \\
\hline 18. & Plastic chair & 27 & 2597 Nos. \\
\hline 19. & Check dam & 1 & 1 \\
\hline 20. & Syntex / water barrels & 3 & 116 Nos. \\
\hline 21. & Retaining wall & 11 & 4039 feet \\
\hline 22. & Hand pump & 1 & 150 feet \\
\hline 23. & Purchase of furniture / utensils & 3 & \\
\hline 24. & Drainage & 6 & 6 Nos. \\
\hline 25. & Sugarcane crushing machine & 7 & 7 Nos. \\
\hline 26. & Pipeline for water reservoir & 10 & 5160 metres \\
\hline 27. & Rice-mill & 4 & 4 Nos. \\
\hline 28. & Agar distillation unit & 1 & 1 Nos. \\
\hline 29. & $\begin{array}{l}\text { Others (Granary, village gate, Basketball court, soil } \\
\text { metailing etc.) }\end{array}$ & 17 & 17 Nos \\
\hline \multicolumn{2}{|r|}{ Overall } & 990 & - \\
\hline
\end{tabular}

(Source: Department of Land resource, Nagaland, 2018) 
Table.2 Different activities implemented under IWMP for the beneficiary

\begin{tabular}{|c|l|c|c|}
\hline S.N. & \multicolumn{1}{|c|}{ Activity Implemented } & Numbers & Per cent \\
\hline $\mathbf{1 .}$ & Trainings & 56 & 16.62 \\
\hline $\mathbf{2 .}$ & Exposure trips & 25 & 7.42 \\
\hline $\mathbf{3 .}$ & Demonstration and Exhibition & 38 & 11.28 \\
\hline $\mathbf{4 .}$ & Distribution of saplings & 78 & 23.15 \\
\hline $\mathbf{5 .}$ & Agri-based activity & 26 & 7.72 \\
\hline $\mathbf{6 .}$ & Animal husbandry & 40 & 11.86 \\
\hline $\mathbf{7 .}$ & Funding of SHG & 62 & 18.39 \\
\hline $\mathbf{8 .}$ & Others & 12 & 3.56 \\
\hline & \multicolumn{1}{|c|}{ Overall } & 337 & 10000 \\
\hline
\end{tabular}

Table.3 Average monthly income of the beneficiary and non-beneficiary

\begin{tabular}{|c|c|c|c|c|c|c|}
\hline \multirow[t]{2}{*}{$\begin{array}{l}\text { Sl. } \\
\text { No }\end{array}$} & \multirow[t]{2}{*}{$\begin{array}{l}\text { Category of } \\
\text { respondent }\end{array}$} & \multirow{2}{*}{$\begin{array}{c}\text { Category of } \\
\text { respondent } \\
\text { according to land } \\
\text { holding }\end{array}$} & \multirow[t]{2}{*}{$\begin{array}{l}\text { No. of } \\
\text { respondent }\end{array}$} & \multicolumn{2}{|c|}{$\begin{array}{l}\text { Average monthly } \\
\text { income (Rs) }\end{array}$} & \multirow{2}{*}{$\begin{array}{c}\text { Increase } \\
\text { in income } \\
\text { (Rs) }\end{array}$} \\
\hline & & & & $\begin{array}{l}\text { Before } \\
\text { IWMP }\end{array}$ & $\begin{array}{l}\text { After } \\
\text { IWMP }\end{array}$ & \\
\hline \multirow[t]{4}{*}{1} & \multirow[t]{4}{*}{ Beneficiary } & Small & 5 & 1000 & 1280 & 280 \\
\hline & & Semi-medium & 16 & 4100 & 4540 & 440 \\
\hline & & Medium & 33 & 4246 & 4787 & 541 \\
\hline & & Large & 26 & 3589 & 4082 & 493 \\
\hline \multicolumn{3}{|c|}{ Total } & 80 & 12,935 & 14,689 & 1,754 \\
\hline \multirow[t]{4}{*}{2} & \multirow{4}{*}{$\begin{array}{c}\text { Non- } \\
\text { beneficiary }\end{array}$} & Small & 4 & 1250 & 1400 & 150 \\
\hline & & Semi-medium & 23 & 2958 & 3393 & 435 \\
\hline & & Medium & 30 & 3433 & 3620 & 187 \\
\hline & & Large & 23 & 4861 & 5222 & 361 \\
\hline \multicolumn{3}{|c|}{ Total } & 80 & 12,502 & 13,635 & 1,133 \\
\hline
\end{tabular}

From the table we can see that constructions of water tank / pond / reservoir has been carried in most of the village with a total of 393 villages, followed by construction of marketing shed in 115 villages, construction of toilet in 75 villages, construction of footstep and waiting shed in 66 villages, construction community hall/repair or renovation of community hall carried out in 56 villages, construction of community kitchen/ guest house/building/post-harvest storage unit carried out in 32 villages, distribution of plastic chairs in 27 villages, construction of ring well carried out in 19 villages, construction of rostrum and approach road /repairing of road are carried out in 18 villages, fencing of project site has been carried out in 16 villages, construction of retaining wall carried out in 11 villages, pipeline for water reservoir is carried out in 10 villages, construction of culvert in 8 villages, sugarcane crushing machine set up in 7 villages, drainage and renovation of school has been carried in 6 villages, generator and rice mill has been set up in 4 villages, construction of community fishery pond, connection of street light / solar light, purchasing of syntex/water barrels, furniture / utensils has been carried out 3 villages, setting up of Bamboo charcoal making hearth, 
check dam, hand pump, agar distillation unit has been carried out in only 1 village each. Miscellaneous work like construction of granary, village gate, basketball court, soil metalling etc; has been carried out in 17 villages. Similar studies were carried out by the Shuya and Sharma (2014); Sharma et al., (2015); Walling et al., (2017); Shuya and Sharma (2018).

Table 2 reveals that the most common activity implemented by IWMP is distribution of saplings followed by funding of SHG, trainings, animal husbandry, demonstration, agri-based activity and exposure trips. Similar studies were find out by the Sharma (2002); Sharma (2004); Dhakre and Sharma (2010); Mishra et al., (2014); Pongener and Sharma (2018).

Table 3 reveals the average monthly income of the beneficiary and non-beneficiary. It was found that there is an increase in the income of for both beneficiary and non-beneficiary but comparatively beneficiary has more increased income.

The medium farmers have higher increased income of Rs 541.00/- as compared to large farmers with Rs 493.00/-, semi-medium with Rs 440.00/- and small with Rs 280.00/-, respectively. Similar studies were carried out by the Sharma (2011); Sharma (2014); Sangtam and Sharma (2015); Sharma et al., (2016); Sharma et al., 2018.

\section{Policy implications}

As per the above findings of the present study the following policy implications may be drawn for the betterment of the study areas:

Information centre should be set up at the block level so that there is timely dissemination of the information to the beneficiary.
More focused should be on skilled based training.

The financial assistance provided by the government for livelihood activity should be enhanced and should be given at the appropriate time.

Training institute should be set up at the block and district level also.

Value added / post-harvest management should be encouraged.

\section{References}

Analogous. 2016. Agricultural Situation in India. Directorate of Economics and Statistics. Ministry of Agriculture, New Delhi.

Analogous. 2017. Statistical Hand of Nagaland Published by Directorate of Economics and Statistics (various issues), Kohima, Nagaland.

Dhakre, D. S. and Sharma, Amod. 2010. Socio-Economic Development in India. Environment and Ecology. 4(1): 24692472.

Mishra, A.; Pattnaik, B. R. and Ray, Plabita. 2014. Impact of Watershed Development Programme on Socioeconomic Development of the People. Journal of Extension Education. 39(1): 182-189.

Pongener, Bendangjungla and Sharma, Amod. 2018. Constraints Faced by the Fishery Enterprises: A SWOC Analysis. IJCMAS. 7(5). May: 1595-1603.

Sangtam, Likhase. L. T. and Sharma, Amod. 2015. Impact of Bank Finance on Employment and Income through Piggery Enterprise in Nagaland. EPRAIJEBR. 3(11). Nov: 273-276.

Sharma, A. 2002. Source and Knowledge on beneficiaries about the purpose of credit - A case study of Agra Region of Uttar 
Pradesh. Journal of Interacademica. 6(3). July: 374-379.

Sharma, A. 2004. Constraints of Fish Production - A case study in rainfed areas of Uttar Pradesh. Journal of Interacademica. 8(4). October: 639643.

Sharma, A. and Sharma, Anamika. 2008. Problems faced by the farmers in adoption of improved maize cultivation practices in hills. TJRAR. 8(2): 22-23.

Sharma, Amod. 2011. Economic and Constraints of King Chilli Growers in Dimapur District of Nagaland. Journal of Interacademicia. 15(4): 710-719.

Sharma, Amod. 2012. Inter-state Disparities in Socio-economic Development in North East Region of India. Journal of Agricultural Science. 4(9). September: 236-243.

Sharma, Amod. 2014. Sustainable economic analysis and extent of satisfaction level of King Chilli growers in Nagaland. Agriculture for Sustainable Development. 2(1). June: 188-191.

Sharma, Amod; Kichu, Yimkumba and Chaturvedi, B. K. 2016. Economics and Constraints of Pineapple Cultivation in Dimapur District of Nagaland. TJRAR. 16(1). January: 72-75.

Sharma, Amod; Kichu, Yimkumba and Sharma, Pradeep. Kumar. 2018. Sustainable economic analysis and constraints faced by the pineapple growers in Nagaland. Progressive
Agriculture. 18(1). February: 27-33.

Sharma, Rajan, Chauhan, Jitendra, Meena, B.

S. and Chauhan, R. S. 2015. Problems

Experienced By Farmers and Project Officers in Watershed Management. Indian Research Journal of Extension Education. 15(2\&3): 23-27.

Shuya, Keviu and Sharma, Amod. 2014. Impact and constraints faced by the borrowers of cooperative bank finance in Nagaland. Economic Affairs. 59(4). October: 561-567.

Shuya, Keviu and Sharma, Amod. 2018. Problems faced by the Borrowers in Utilization and Acquiring of Cooperative Bank Loans in Nagaland. IJED. 14(2). April-June: 52-56.

Tangjang, Avicha and Sharma, Amod. 2018. Problem faced by the Large Cardamom Growers during production and marketing: A case study of Tirap district of Arunachal Pradesh. IJCMAS. 7(5). May: 2561-2573.

Walling, Imti. and Sharma, Amod. 2015. Impact of SGRY on beneficiaries and non-beneficiaries in Dimapur district of Nagaland. TJRAR. 15(2). August: 9094.

Walling, Imti; Sharma, Amod.; Yadav, Mukesh. Kumar.; Rajbhar, Arun, Kumar. and Kalai, Kankabati. 2017. Impact of Agricultural Technology Management Agency on Rural Economy of Nagaland, India. Plant Archiver. 17(2). October: 1511-1516.

\section{How to cite this article:}

Kanitoli Chishi, S. and Amod Sharma. 2019. Assured Income of Beneficiary and NonBeneficiary through Different Activities Implemented under IWDP Programme in Nagaland. Int.J.Curr.Microbiol.App.Sci. 8(06): 2304-2309. doi: https://doi.org/10.20546/ijcmas.2019.806.273 